\title{
Post-mortem viral dynamics and tropism in COVID-19 patients in correlation with organ damage
}

\author{
Kristijan Skok $^{1} \cdot$ Evelyn StelzI ${ }^{2} \cdot$ Michael Trauner $^{3} \cdot$ Harald H. Kessler $^{2} \cdot$ Sigurd F. Lax ${ }^{1,4}$ (D)
}

Received: 19 June 2020 / Revised: 22 July 2020 / Accepted: 6 August 2020 / Published online: 20 August 2020

(C) The Author(s) 2020

\begin{abstract}
The persistence of SARS-CoV-2 after death of infected individuals is unclear. The aim of this study was to investigate the presence of SARS-CoV-2 RNA in different organs in correlation with tissue damage and post-mortem viral dynamics in COVID19 deceased. Twenty-eight patients (17 males, 11 females; age 66-96 years; mean 82.9, median 82.5 years) diagnosed with COVID-19 were studied. Swabs were taken post-mortem during autopsy $(N=19)$ from the throat, both lungs, intestine, gallbladder, and brain or without autopsy $(N=9)$ only from the throat. Selective amplification of target nucleic acid from the samples was achieved by using primers for ORF1a/b non-structural region and the structural protein envelope E-gene of the virus. The results of 125 post-mortem and 47 ante-mortem swabs were presented as cycle threshold $(\mathrm{Ct})$ values and categorized as strong, moderate, and weak. Viral RNA was detected more frequently in the lungs and throat than in the intestine. Blood, bile, and the brain were negative. Consecutive throat swabs were positive up to $128 \mathrm{~h}$ after death without significant increase of $\mathrm{Ct}$ values. All lungs showed diffuse alveolar damage, thrombosis, and infarction and less frequently bronchopneumonia irrespective of $\mathrm{Ct}$ values. In 30\% the intestine revealed focal ischemic changes. Nucleocapsid protein of SARS-CoV-2 was detected by immunohistochemistry in bronchial and intestinal epithelium, bronchial glands, and pneumocytes. In conclusion, viral RNA is still present several days after death, most frequently in the respiratory tract and associated with severe and fatal organ damage. Potential infectivity cannot be ruled out post-mortem.
\end{abstract}

Keywords COVID-19 $\cdot$ SARS-CoV-2 $\cdot$ Post-mortem $\cdot$ PCR $\cdot$ Immunohistochemistry bowel

This article is part of the Topical Collection on Quality in Pathology

Electronic supplementary material The online version of this article (https://doi.org/10.1007/s00428-020-02903-8) contains supplementary material, which is available to authorized users.

Sigurd F. Lax

sigurd.lax@kages.at

1 Department of Pathology, Hospital Graz II, Academic Teaching Hospital of the Medical University of Graz, Goestingerstrasse 22, AT-8020 Graz, Austria

2 Diagnostic \& Research Institute of Hygiene, Microbiology and Environmental Medicine, Medical University of Graz, Neue Stiftingtalstrasse 6, AT-8010 Graz, Austria

3 Division of Gastroenterology and Hepatology with Intensive Care 13H1, Department of Internal Medicine III, Vienna General Hospital, Medical University of Vienna, Waehringerguertel 18-20, AT-1090 Vienna, Austria

4 School of Medicine, Clinical Institute of Pathology and Molecular Pathology, Johannes Kepler University Linz, Huemerstrasse 3-5, AT-4020 Linz, Austria

\section{Introduction}

The coronavirus disease 2019 (COVID-19) caused by the severe acute respiratory syndrome (SARS)-coronavirus-2 (CoV-2) has become a pandemic and shaken economy, societies, and national healthcare systems worldwide [1]. SARS$\mathrm{CoV}-2$ has been categorized into the ACDP hazard group 3, which means that (1) the hazard may lead to severe human disease and can be a significant risk to laboratory employees, (2) the virus can be transmitted to other people, and (3) prophylaxis and/or treatment are generally accessible [2]. The currently established potential transmission route is personto-person, mainly via respiratory aerosols and droplets when an infected person coughs, sneezes, sings, shouts, or talks [3]. The risk of transmission depends on several factors such as the type and duration of exposure, the use of preventive measures, and individual factors (e.g., the amount of virus in respiratory secretions) [4]. Virus-contaminated surfaces can also be a potential source of infection including transmission of the virus to the mucous membranes of the individual, in particular the 
nose, eyes, and mouth $[4,5]$. Infections in healthcare units, including long-term care facilities, are of utmost concern $[6$, 7]. The infectivity of a person also remains unclear. The virus can be detected in various clinical samples, depending on the severity of symptoms in pharyngeal swabs up to 42 days [ 8 , 9]. In addition to the respiratory tract, the gastrointestinal tract has received increasing attention as site of viral replication and shedding via feces $[10,11]$.

Post-mortem examinations provide important insights for the study of novel diseases and the clarification of unknown causes of death and are considered an integral part of a qualityassessed healthcare system. Especially in the case of infectious diseases, the safety protection for the examination team is crucial and requires profound knowledge of the potential virulence of an infectious agent. Therefore, it is important to determine whether SARS-CoV-2 is capable to replicate after death of the infected individual and thereby potentially may cause an infection. Pathologists may fear infection while performing autopsies and may therefore avoid them, thus precluding urgently needed pathomechanistic insights into a hereto poorly understood disease.

There is a number of studies dealing with viral dynamics of SARS-CoV-2, but to the best of our knowledge, no study has analyzed the post-mortem setting in correlation with additional ante-mortem reference points. The aim of this study was to determine the temporal-spatial distribution of SARS-CoV-2 in post-mortem swabs of COVID-19 deceased. We used a technically feasible and robust semi-quantitative approach which is widely used for the assessment of the potential infectivity of an individual and further correlated the load of viral RNA with changes in lungs and bowel as frequently involved organs.

\section{Materials and methods}

\section{Patients characteristics}

This prospective study was carried out at the Department of Pathology of the Hospital Graz II, an academic teaching hospital of the Medical University of Graz and the Molecular Diagnostics Laboratory of the Medical University of Graz. From March 24, 2020, to May 13, 2020, 68 patients aged from 66 to 99 (30 female, 38 males, mean 82.91, median 82) died due to COVID-19 in our hospital. Twenty-eight deceased COVID-19 patients were included of which 19 underwent autopsy. All included patients fulfilled the WHO criteria for COVID-19 (www.who.int). They presented with fever and acute respiratory symptoms including cough and shortness of breath and were tested positively for SARS-CoV-2 RNA by PCR either before or at admission to our hospital. The selection of these patients was performed at random and only influenced by our infrastructural, time, and personnel constraints under the challenging pandemic situation. There were no medical exclusion criteria. All deceased patients were brought from the ward to a morgue with a standardized ambient temperature of $4{ }^{\circ} \mathrm{C}$ within $2 \mathrm{~h}$ after death. Eight of the 19 autopsy cases were included in a previous study, which focused on the clinicopathological findings and did not investigate the viral load of the patients [12].

\section{Post-mortem sampling}

Swabs from other anatomic regions than the pharynx could only be taken from the patients who underwent autopsy. All swabs were taken by the same investigator (K.S.). To investigate the presence of viral RNA after death, the autopsy procedure included post-mortem swabs from the throat and other organs (both the lungs, colon, small intestine, gallbladder, cerebrospinal fluid/brain, and blood). The lung swabs were taken separately from each side of the bronchial system. The swabs from the bowel were taken from the mucosa mostly from the sigmoid colon after incision of the bowel wall using a fresh scalpel. The cerebrospinal fluid/brain swab was taken from the lateral ventricles by crossing the corpus callosum. To avoid cross-contamination, fresh scissors or scalpels were used whenever required. Consecutive throat swabs after autopsy at a 24-h interval were taken from the nasopharynx. In addition, consecutive post-mortem throat swabs were taken from 9 deceased COVID-19 patients who did not undergo autopsy. Results of ante-mortem swabs were retrieved for 25 patients from the database of the Laboratory of Molecular Diagnostics of the Medical University of Graz; for 3 patients, the analysis had been performed in an outside lab, and $\mathrm{Ct}$ values were not available. All performed procedures and investigations were in accordance with the ethical standards of the institutional research committee and with the 1964 Helsinki declaration and its later amendments. According to federal Austrian law for public hospitals, autopsies are mandatory without informed consent from the relatives due to scientific or public interest, particularly, if the cause of death is uncertain.

\section{Viral RNA analysis, correlation with pathological findings, and demonstration of intracellular viral protein by immunohistochemistry}

The sampling was done according to the same protocol as described in our previous study [12]. Swabs were collected by using Copan ESwab ${ }^{\mathrm{TM}}$ collection system containing $1 \mathrm{~mL}$ of transport medium and stored at $2-8{ }^{\circ} \mathrm{C}$ until transported to the Molecular Diagnostics Laboratory, Medical University of Graz. Samples were tested for SARS-CoV-2 RNA within $12 \mathrm{~h}$ of arrival. The presence of SARS-CoV-2 RNA was determined by real-time PCR (qPCR) using the in vitro diagnostics/Conformité Européenne (IVD/CE)-labeled Cobas® SARS-CoV-2 test (Roche Molecular Systems, Branchburg, 
NJ, USA) for use on the Cobas ${ }^{\circledR} 6800 / 8800$ system (Roche Molecular Diagnostics, Rotkreuz, Switzerland) [13, 14]. Selective amplification of target nucleic acid from the sample was achieved by the use of target-specific forward and reverse primers for ORF1a/b non-structural region that is unique to SARS-CoV-2. In addition, a conserved region in the structural protein envelope E-gene was chosen for pan-sarbecovirus detection. The pan-sarbecovirus detection set also detects SARS-CoV-2 virus.

The results were presented as cycle threshold $(\mathrm{Ct})$ values. The $\mathrm{Ct}$ is defined as the number of cycles required for the fluorescent signal to cross the threshold (i.e., exceeds background level). Ct levels are inversely proportional to the amount of target nucleic acid in the sample (i.e., the lower the $\mathrm{Ct}$ level, the greater the amount of target nucleic acid in the sample). The $\mathrm{Ct}$ values obtained by qPCR were sorted, grouped into 3 categories $(<25$, strongly positive; $25-35$, moderately positive; $>35$ weakly positive) and statistically analyzed.

The viral data from the lungs and the colon were correlated with the organ damage as determined by histopathological examination. The technique for grossing and sampling of the lungs has been previously detailed [12]. In brief, both lungs were totally fixed in formalin and sliced after fixation from the apex to the basis. Multiple samples were processed from each lobe, partially using giant sections. The colon was sampled from the area where the swab was taken. The diffuse alveolar damage was categorized according to stage $[15,16]$, and the severity of lung damage was appreciated based on the extent of inflammatory and vascular changes and graded using a 3-tiered scale (mild, moderate, severe). We considered focal inflammatory changes in the absence of infarction as mild, extensive inflammation with thrombosis and/or infarction involving at least large parts of a lobe as severe and all changes in between as moderate.

To demonstrate the virus in situ, samples from the lungs and the colon of one representative RNA-positive case were analyzed by immunohistochemistry using a mouse monoclonal antibody against the SARS-CoV-2 nucleocapsid protein (clone 4B21, Creative Diagnostics, Shirley, NY, USA). The analysis was performed on a Ventana Benchmark Ultra ${ }^{\mathrm{TM}}$ system (Roche Diagnostics, Indianapolis, IN, USA) with a concentration of 1:250 for the primary antibody. A brown intracytoplasmic reaction product was considered positive. For negative controls, tissue from non-COVID-19 cases was used.

Statistical analysis and presentation of results were performed using Microsoft Excel Office 365 (Microsoft), GraphPad Prism version 8.0 (GraphPad Software, La Jolla California USA) and SPSS Statistics for Windows, version 25.0 (IBM Corp., Armonk, NY).

\section{Results}

All patients were Caucasians, 17 males and 11 females (age range $66-96$, mean 82.9 , median 82.5 years). The time from onset of symptoms to death took from 4 to 36 days (mean 12.3 days) and the duration of hospitalization from 4 to 35 days (mean 11 days). A total of 125 swabs were collected prospectively post-mortem from the throat $(N=57)$, lungs $(N=38 ; 19$ from each side), colon $(N=13)$, cerebrospinal fluid and brain $(N=7)$, gallbladder $(N=4)$, small intestine $(N=2)$, and blood $(N=4)$ at 24 -h intervals. Data from 47 ante-mortem throat swabs (before and during hospitalization) were available for 25 patients. The number of post-mortem swabs from one patient ranged from 1 to 7 ; the number of ante-mortem swabs ranged from 1 to 10 .

\section{Analysis of the samples}

For 22 patients, the initial post-mortem swabs were positive; for the remaining 6 patients, all post-mortem swabs were negative, and in 3 of these 6 patients also, the last ante-mortem swab had been negative. Subsequent post-mortem swabs were taken in 14 patients, and the results of the first post-mortem swab remained positive (11 patients) or negative (3 patients). In 9 of these, 14 patients at least 3 swabs were taken ( 8 positive), and in 4 of the 14 patients, at least 4 swabs were taken (all 4 positive). The result of the first post-mortem swab remained either positive or negative throughout all consecutive swabs. A switch from a positive ante-mortem to a negative post-mortem throat swab was found in 3 patients ( 2 underwent autopsy) of whom one had positive post-mortem swabs from the right lung and the colon. In 3 cases, 2 with autopsy, the last ante-mortem and all post-mortem throat swabs were negative. The results are detailed on Fig. 1a.

The anatomical distribution is demonstrated on Fig. $1 \mathrm{~b}$. Lung swabs were positive in 17/19 (right lung; average $\mathrm{Ct}$ value 28.53) and 16/19 (left lung; average Ct value 29.01) cases, respectively. Most lung swabs fell into the strongly or moderately positive category, whereas none of the intestinal swabs was strongly positive. Swabs from the colon were positive in 5/13 cases (average $\mathrm{Ct}$ value 32.44 ) and from the small intestine in $1 / 2$ cases (average $\mathrm{Ct}$ value 35.75). In 2 colon swabs, the PCR reaction was inhibited which means that the detection of the internal control failed due to inhibitory agents such as feces, bile, salts, or complex polysaccharides. All swabs from blood, gallbladder, and cerebrospinal fluid/brain tissue were negative. Due to several negative results, we analyzed only a limited number of samples from blood and the gallbladder.

The $\mathrm{Ct}$ values for the throat swabs reveal a trend to a slight but not statistically significant increase from the ante-mortem to the post-mortem period (average $\mathrm{Ct}$ value 28.12 postmortem compared with 27.68 ante-mortem) (Fig. 2a). The 


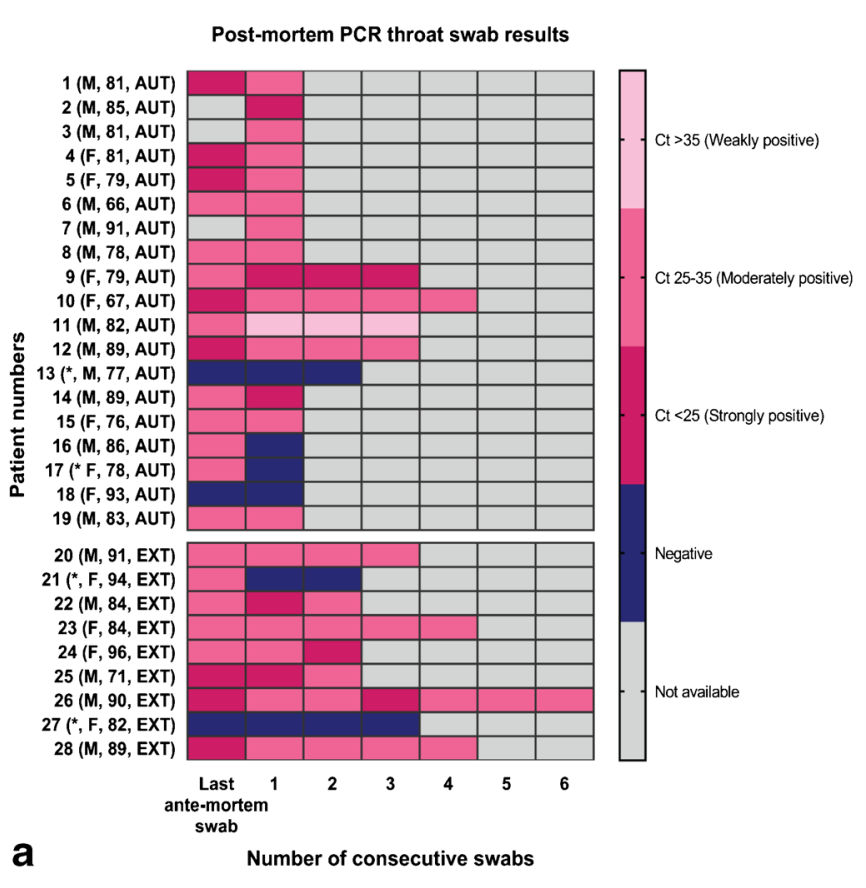

Fig. 1 Distribution of qPCR results (according to $\mathrm{Ct}$ values) of the collected samples. The post-mortem swab qPCR results from throat (a) and all organs (b) are shown as heatmaps. qPCR results are grouped as

$\mathrm{Ct}$ values for the individual anatomical regions are distributed among all 3 semi-quantitative categories with a predominance of moderate positivity (Fig. 2b). Subsequent swabs from one patient may show a variation of the $\mathrm{Ct}$ values over time as demonstrated for 2 cases (Fig. 2c). The variability of $\mathrm{Ct}$ values with intermittent negativity is showed in another patient with multiple swabs over 36 days of hospitalization (Fig. 2d). Neither the differences of $\mathrm{Ct}$ values from the throat $(M=$ 28.5713, $\mathrm{SD}=5.11)$ and from the lungs $(M=28.32, \mathrm{SD}=$ 5.26) were statistically significant $(t(14)=0.18 ; p=0.548$; paired samples $t$ test) nor of throat swabs before $(M=27.68$, $\mathrm{SD}=5.44)$ and after death $(M=28.12, \mathrm{SD}=3.92)(t(-0.4)=$ $76 ; \mathrm{p}=0.548$; independent sample $t$ test).

\section{Correlation of $\mathrm{Ct}$ values with degree of organ damage}

The pathological changes of the lungs confirmed our previous findings [12]. Macroscopically, both lungs showed massive congestion in the dorsobasal segments (hypostasis); the pleura was inconspicuous in most cases. The most striking features are thrombotic occlusions of small- to mid-sized pulmonary arteries which were grossly visible (Fig. 3a) and histologically confirmed and often associated with infarction and infarctionlike changes (Fig. 3a, b). Histologically, we also found thrombosis of smaller arteries with less than $1 \mathrm{~mm}$ in diameter (Fig. 3c). In all cases, the lung parenchyma showed a diffuse alveolar damage (DAD) at various stages and in varying degrees characterized by edema and hyaline membranes (acute

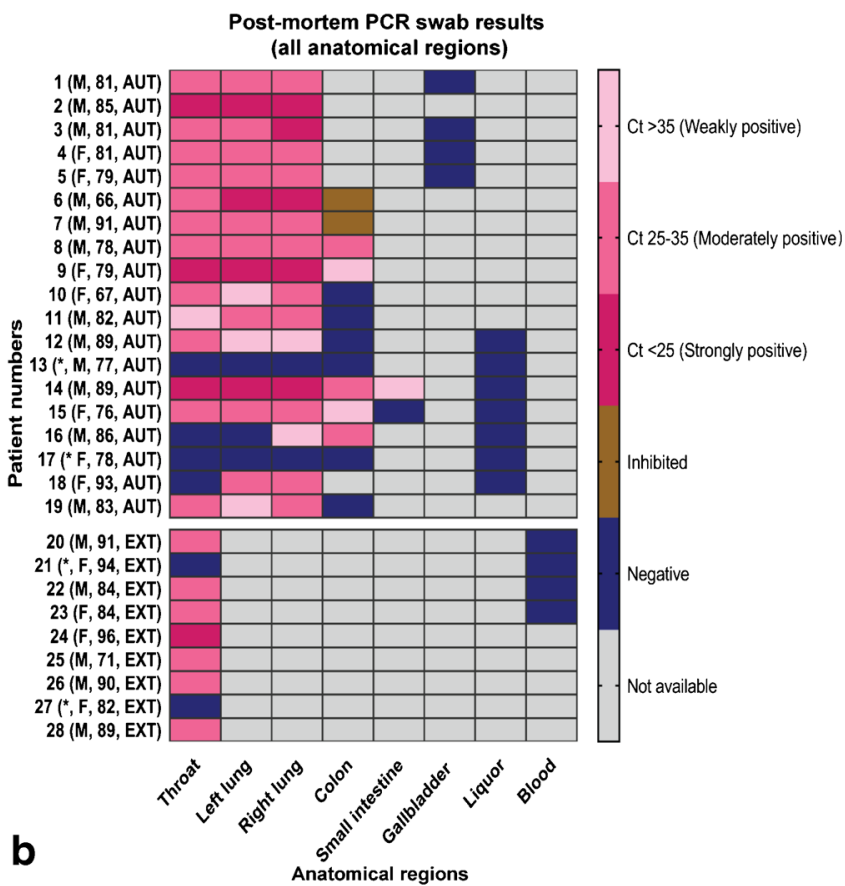

weakly, moderately and strongly positive, negative, and inhibited. M, male; F, female; AUT, autopsy; EXT, external examination. *Patients with exclusively negative post-mortem results

or exudative phase), proliferation of pneumocytes and fibroblasts with organization of the hyaline membranes (subacute or organizing phase), and in some cases also interstitial fibrosis and organizing pneumonia (fibrotic or chronic phase) (Fig. 3d-f). In a subset of cases, the proliferative phase was associated with reactive atypical changes of the pneumocytes and squamous metaplasia. Three quarters of the cases showed mostly focal bronchopneumonia mostly associated with purulent bronchitis. The degree of organ damage was severe in 12 cases and moderate in 7 cases. The pathological findings are detailed in Table 1.

The bowel was grossly inconspicuous in all cases including the peritoneal surface but on histological examination revealed focal ischemic changes limited to the mucosa in 6 cases. The ischemic changes were characterized by atrophic crypts, cryptitis, ulceration, and hemorrhage (Fig. 4). Except for one case, they were present in patients with long duration of disease. No other pathological changes were found.

The individual $\mathrm{Ct}$ values did not correlate with the severity of organ damage. However, $\mathrm{Ct}$ values were lower in the lungs reflecting a higher RNA load compared with the intestines, and the lungs were significantly more often positive than the bowel ( $p=0.028$; chi $^{2}$ test with Yates correction). Notably, the degree of organ damage was moderate or severe in the lungs in all cases, whereas it was mild and focal in the bowel and present only in about $30 \%$ of the cases. The Ct values for the non-autopsy cases were correlated with the duration of disease and hospitalization, respectively, which did not reveal 


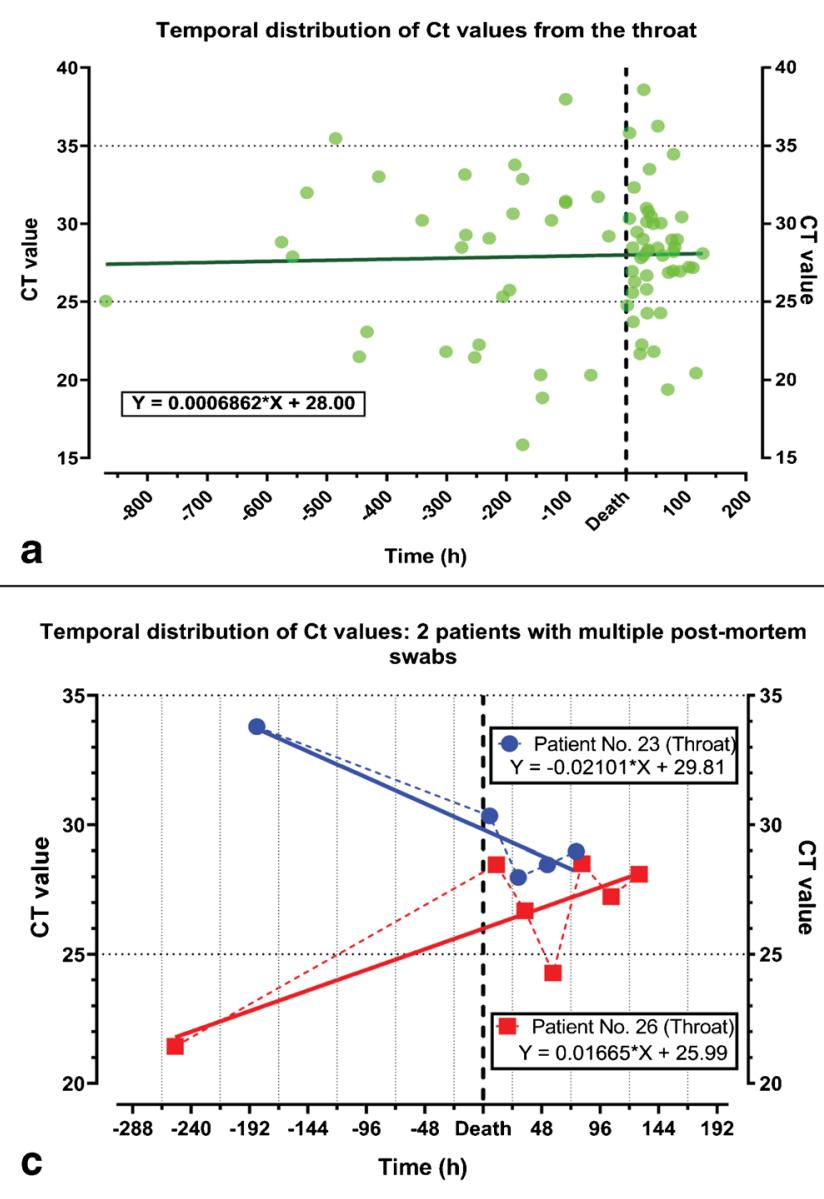

Fig. 2 Temporal distribution of $\mathrm{Ct}$ values of all pharyngeal swabs from 24 post-mortem positive patients (a) and numeric distribution of all swabs (b). Temporal distribution of the $\mathrm{Ct}$ values in two patients with multiple

statistical significance (supplementary table). Viral nucleocapsid protein could be demonstrated by immunohistochemistry in the respiratory epithelium and in the mucous glands of the bronchi as well as in pneumocytes (Fig. 5a). In the colon, the viral protein was detected in the surface and crypt epithelium (Fig. 5b).

\section{Discussion}

In this study, we performed consecutive post-mortem sampling from the pharynx and found viral RNA up to $128 \mathrm{~h}$ after death with only a slow decrease of positivity. We further demonstrate that the throat and lungs are most frequently affected irrespective of the positivity of the pharyngeal swab and show only slight differences of the average $\mathrm{Ct}$ values. This is in contrast to a recent autopsy study which reported clearly higher viral load in the lungs compared with the pharynx by using a different sampling method [17]. Our findings further suggest that viral RNA is less frequently found in intestinal tissue compared with the respiratory tract and the distribution
Distribution of CT values from different anatomical regions
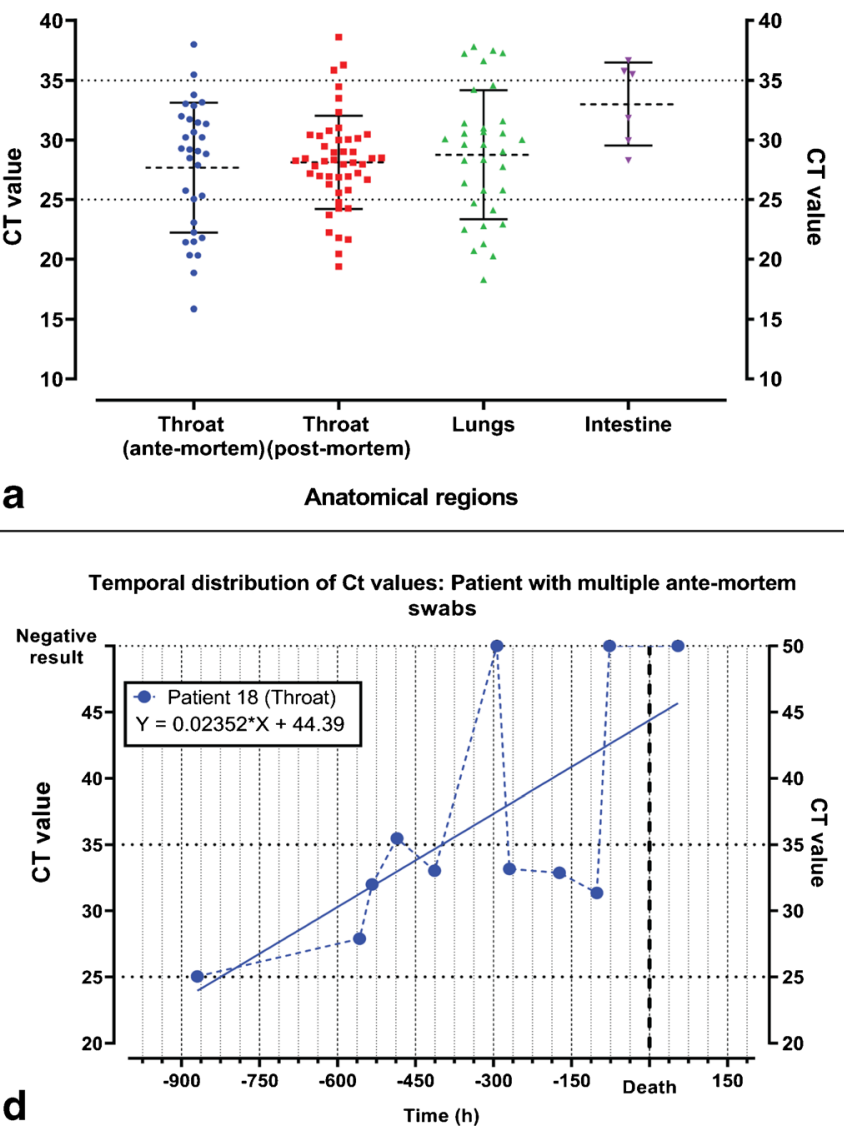

post-mortem swabs (c) and in a patient with 10 ante-mortem and one post-mortem swabs (d)

between the two sites varies. This could be demonstrated in four cases with negative intestinal swabs but positive throat and lung swabs. On the other hand, we were able to detect viral RNA in the colon in one case where swabs from the throat and the left lung were negative. This is in line with recent reports on positive fecal viral RNA in the absence of positive nasopharyngeal swabs $[10,11,18]$. Previous reports suggest that SARS-CoV-2 RNA is significantly longer to be detected in stool samples than in samples from the respiratory tract [19]. Viral organotropism in our study is discrepant to some clinical studies, which report viral RNA in conjunctival swabs, blood samples, gastric juice, feces, anal swab, and urine [20-23]. In this study, we neither found viral RNA in swabs from blood nor in swabs from the brain and cerebrospinal fluid, but the number of analyzed samples from these anatomical areas was limited. Viral RNA was detected at low levels in brain tissue and blood samples by another autopsy study which, in contrast to us, performed viral analysis by qPCR on homogenized frozen tissue and in addition in situ hybridization and immunofluorescence on formalin-fixed, paraffin-embedded tissue [17]. 

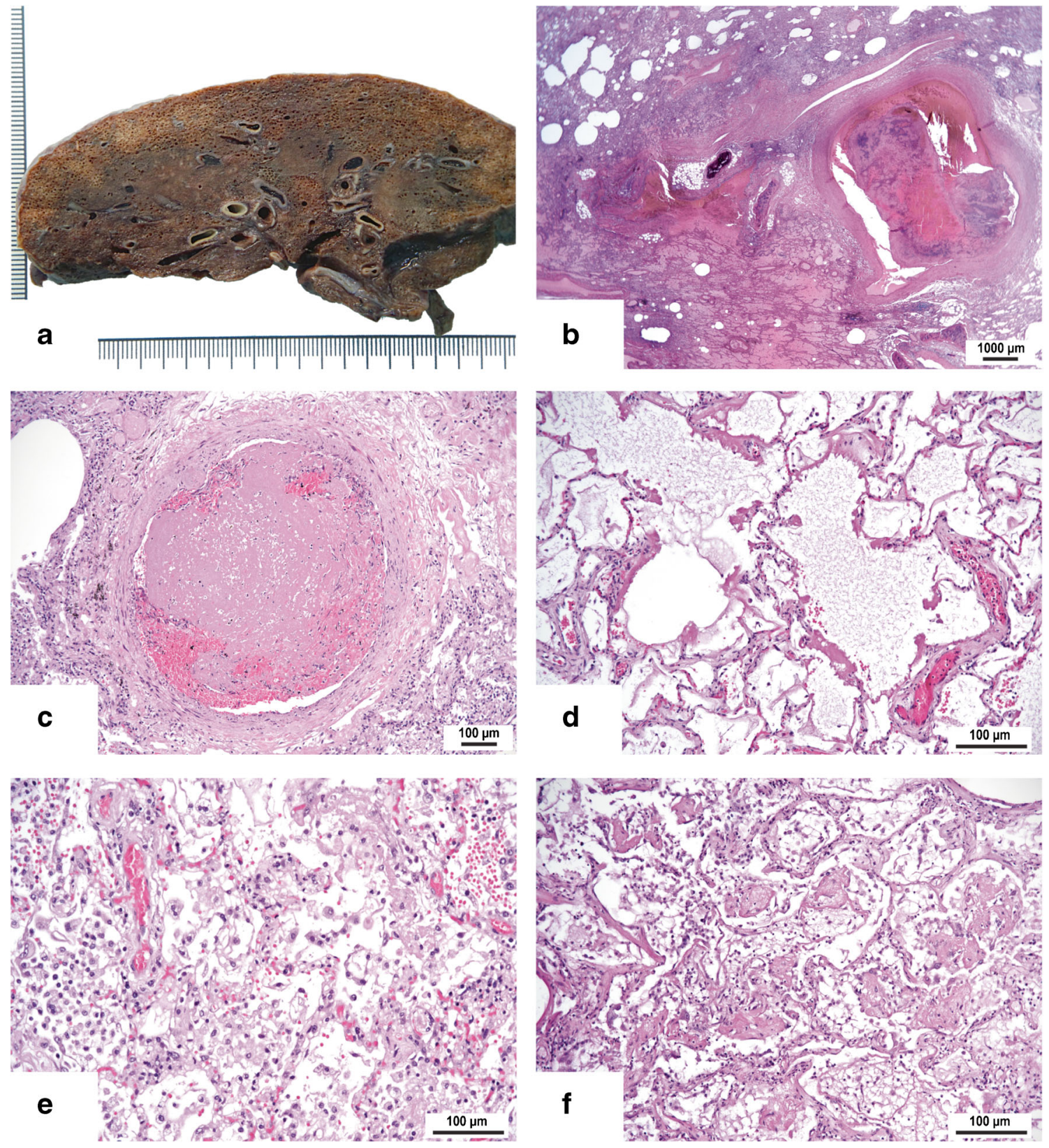

Fig. 3 Cross section through the inferior lobe with congestion, thrombotic material in multiple arteries, and induration of the lung tissue (a). Hemorrhagic infarction of lung tissue adjacent to a mid-sized pulmonary artery with thrombotic material (b). Occlusion of a small artery by a thrombus ("microthrombus") without infarction of the

The degree of organ damage does not show any correlation with the $\mathrm{Ct}$ values, neither within one organ nor between different organs. In particular, pathological changes of the lungs are by far more severe and extensive than the focal ischemic alterations of the intestines. In the lungs, both the diffuse alveolar damage involving the parenchyma and the vascular occlusions by thrombotic material contribute to the massive cardiorespiratory failure and terminal breakdown [12, 24]. It is likely that the pathomechanisms induced by the SARS-CoV-2 infection and leading to organ damage are different between

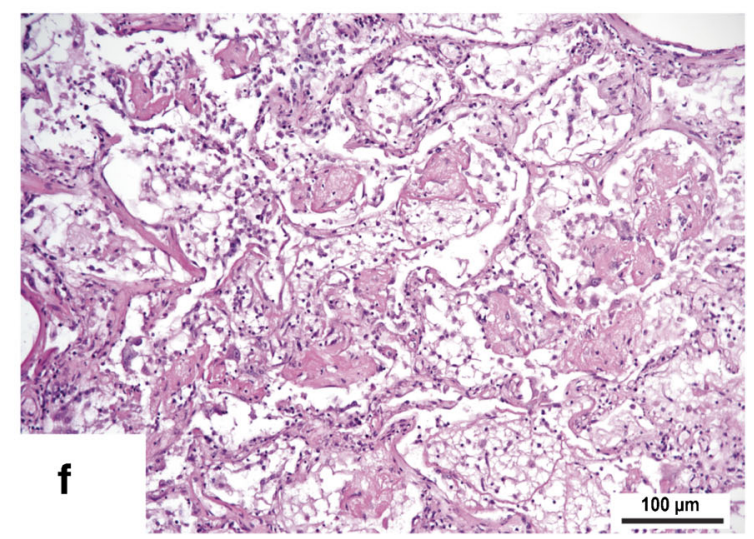

surrounding lung tissue (c). Different stages of diffuse alveolar damage with hyaline membranes and edema (d), proliferation of alveolar macrophages with cellular atypia (e), and proliferation of fibrous tissue with organizing pneumonia-like pattern (f). HE (b-f), original magnifications $\times 10(\mathbf{b}), \times 100(\mathbf{c})$, and $\times 200(\mathbf{d}-\mathbf{f})$

the lung and intestines and are responsible for distinct patterns of response. The lung parenchyma seems to respond to SARSCoV-2 infection by a similar mechanism compared with shock, toxins, and other viral agents which causing acute lung injury. Diffuse alveolar damage, the histological substrate of acute respiratory distress syndrome (ARDS), belongs to its spectrum $[25,26]$. Obviously, the formation of hyaline membranes is caused by a direct injury of the cells lining the bloodair barrier, in particular endothelial cells and pneumocytes through the virus and a breakdown of the barrier [25]. In a 


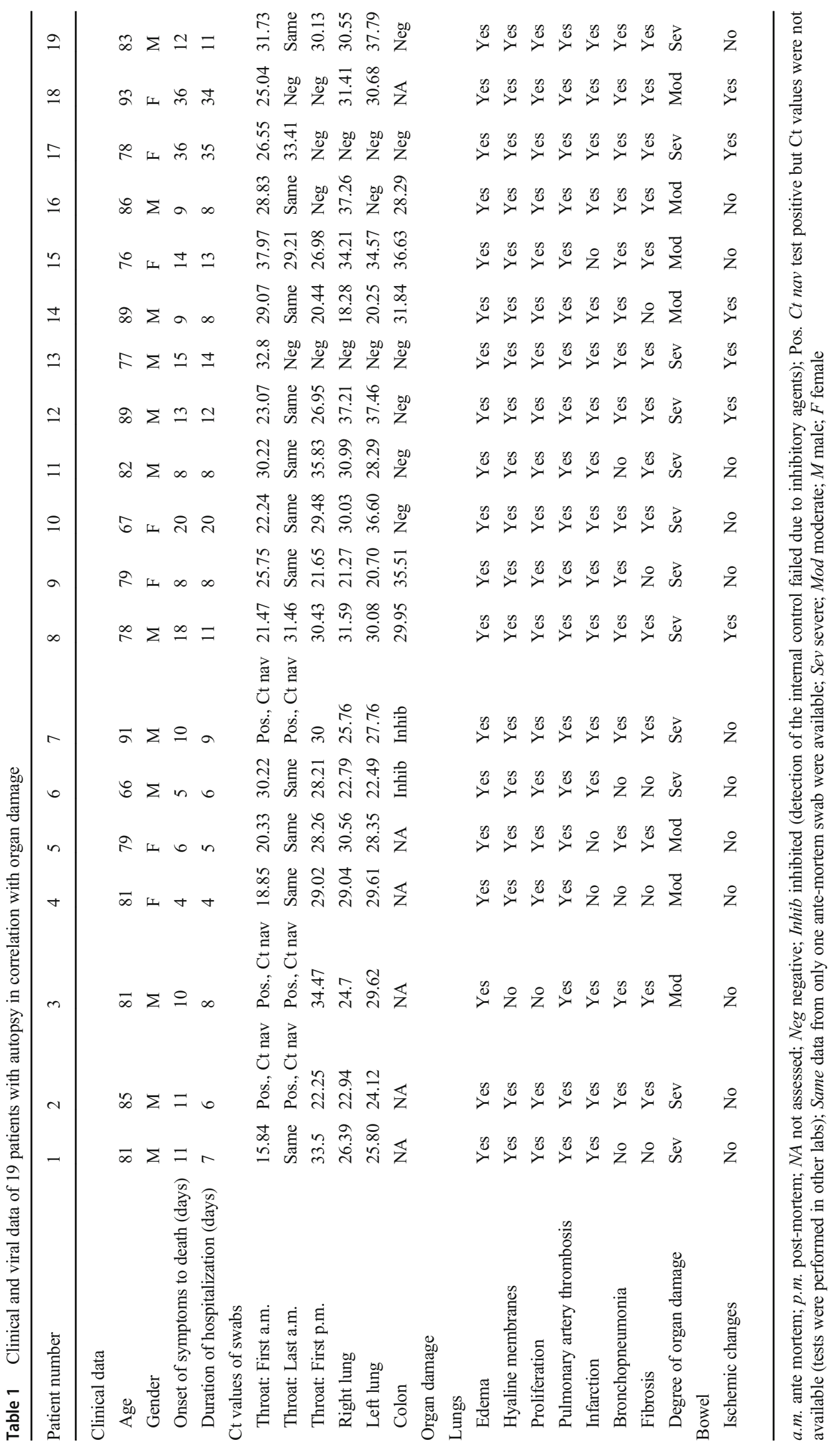



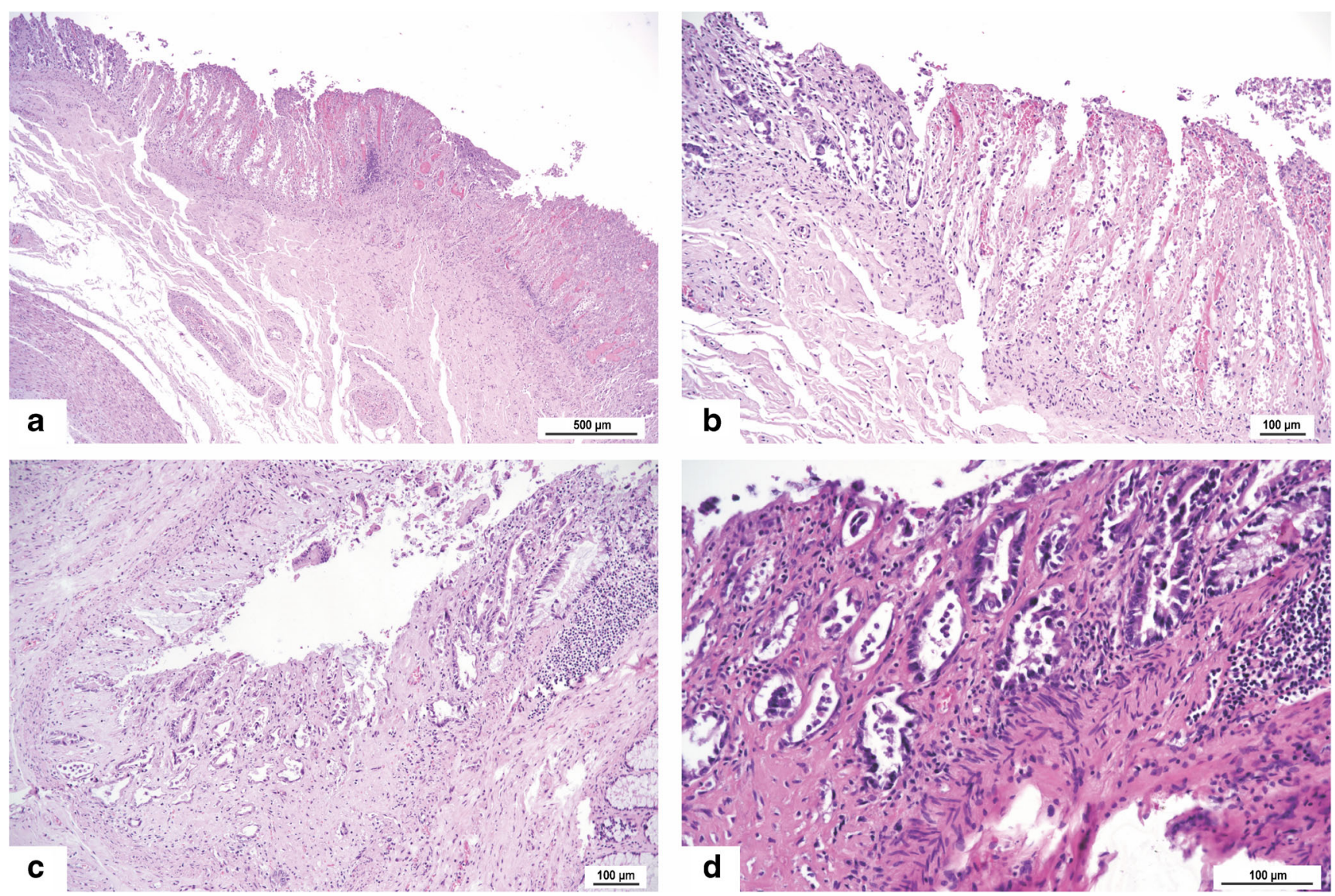

Fig. 4 Ischemic colopathy of different extent but limited to the mucosa: Necrosis and hemorrhagic $(\mathbf{a}, \mathbf{b})$ and atrophic crypts with cryptitis containing neutrophils $(\mathbf{c}, \mathbf{d})$. HE, original magnifications $\times 40(\mathbf{a}), \times 100(\mathbf{b}, \mathbf{c})$, and $\times 200$ (d)

recent study, viral protein was massively detected in pneumocytes besides the bronchial epithelium and the bronchial mucosal glands [27], which we could also demonstrate. It is unclear whether the subsequent stages of diffuse alveolar damage including the arterial thrombosis are stimulated and propagated by the virus or whether their severity depends mainly on the degree of tissue alteration by the initial infection as "first hit." On the other hand, the pathological changes of the bowel seem to be limited to ischemic changes ("ischemic colitis") with focal, often microscopic mucosal lesions. They might rather reflect multiorgan failure due to breakdown of the systemic circulation than direct viral injury although viral protein could be detected within the colon epithelium by immunohistochemistry.
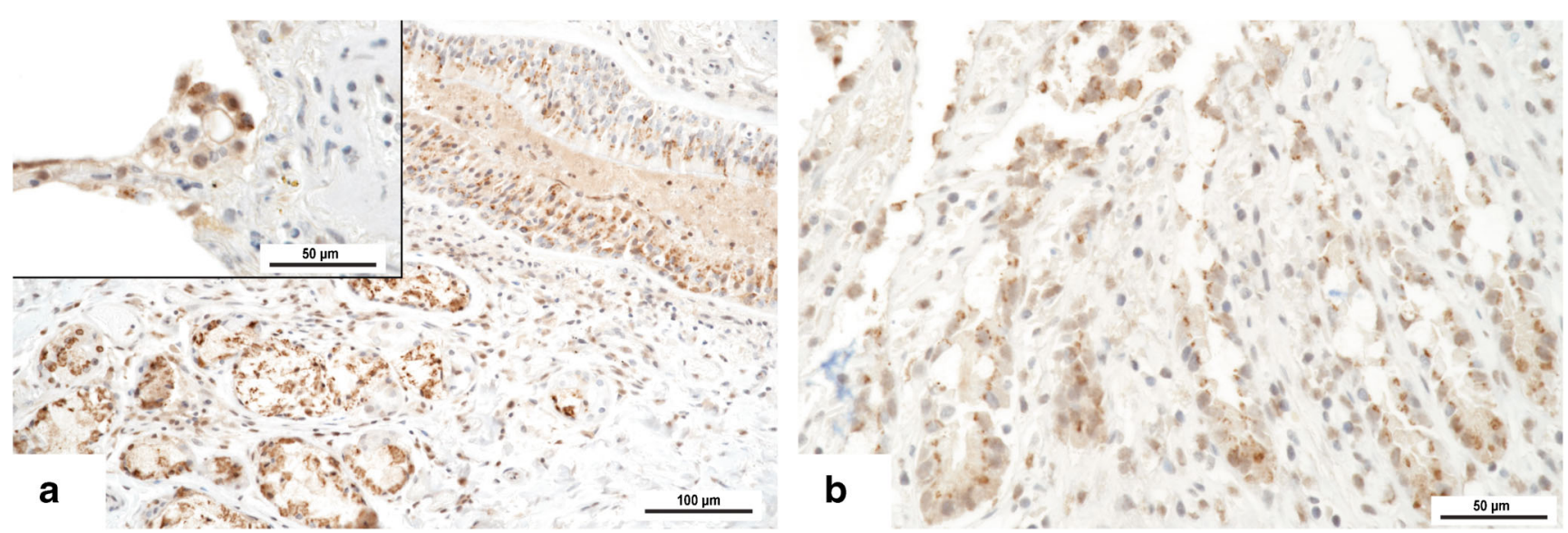

Fig. 5 SARS-CoV-2 nucleocapsid protein in bronchial epithelium, bronchial mucus glands, and pneumocytes (insert) (a) and in intestinal epithelium of the crypts (b). DAB, original magnifications $\times 200(\mathbf{a}, \mathbf{b})$ and $\times 400$ (insert of a) 
The temporal dynamics of SARS-CoV-2 are crucial for its potential virulence particularly in the post-mortem setting. This has been investigated previously for SARS-CoV-1 [28]. In this study, we used Ct values for a semi-quantitative approach to assess and compared the viral load over a certain time period. If viral RNA was detectable within 24-h postmortem, it remained detectable without a significant increase of the $\mathrm{Ct}$ value. On the other hand, if viral RNA was not detectable within 24-h post-mortem, the case remained negative. We are aware that the $\mathrm{Ct}$ values do not correspond with infectivity, although high $\mathrm{Ct}$ values represent a low viral RNA load and harbor a lower probability of transmission of infection. In fact, infectivity could only be determined using viral cultures [29], but this was unfortunately beyond the scope of the current study. Recently, vital virus could be transferred from lung samples from autopsies performed 6-day postmortem and cultivated in cell cultures but without reporting $\mathrm{Ct}$ values [30]. On the other hand, a recent correlation of $\mathrm{Ct}$ values with successful isolation of virus in cell cultures suggested that patients with Ct values above 33-34 were no longer contagious [31]. Furthermore, in a study of nine patients with mild COVID-19, infectious virus was not detected from respiratory specimens when the viral RNA level was $<10^{6}$ copies/mL [29]. This information might be considered for discontinuation of isolation in patients recovering from COVID-19 and for post-mortem examination and autopsies but lacks certainty and requires confirmation. In addition, the methodology of various studies has been heterogenous and inconsistent [32].

We are aware that our study has certain limitations, particularly, by the small number of included cases, the varying number of tested samples among the different cases, and the semi-quantitative method. The varying number of samples was particularly influenced by the time the deceased stayed in our morgue. Viral culture was beyond the scope of the current study; in addition, it is laborious, not widely available, and requires several weeks to obtain results. Further studies will have to explore the infectious potential of RNA-positive samples post-mortem. Nevertheless, to the best of our knowledge, this is the first study that shows the temporal dynamics of SARS-CoV-2 in the post-mortem setting including a correlation with ante-mortem data.

In conclusion, the severity of parenchymatous and vascular pulmonary changes in fatal COVID-19 cannot be explained simply by the degree of the viral RNA load in the respiratory system. Further studies will have to explore the role of other mechanisms including an overwhelming host immune reaction. Finally, our findings also suggest the importance of postmortem testing before autopsy and of careful safety procedures since viral RNA may be still detectable and despite moderately to weakly positive $\mathrm{Ct}$ values a potential virulence cannot be ruled out.
Acknowledgments The authors thank Mrs. Elisabeth Raudner for her skillful technical assistance.

Authors' contributions Study conception and design: K. Skok, H.H. Kessler, and S.F. Lax. Acquisition of data: K. Skok, E. Stelzl, H.H. Kessler, and S.F. Lax. Analysis and interpretation of the data: K. Skok, E. Stelzl, M. Trauner, H.H. Kessler, and S.F. Lax. Drafting of the article: K. Skok and S.F. Lax; Critical revision: K. Skok, E. Stelzl, M. Trauner, H.H. Kessler, and S.F. Lax. S.F. Lax and H.H. Kessler have contributed equally to this manuscript.

Funding information Open access funding provided by Johannes Kepler University Linz.

\section{Compliance with ethical standards}

Conflict of interest Dr. Lax reports personal fees from Roche, AstraZeneca, Novartis, and Biogena outside the submitted work. Dr. Trauner has received speaker fees from Bristol-Myers Squibb, Falk, Gilead, Intercept and Merck Sharp \& Dohme (MSD); advisory board fees from Albireo, Boehringer Ingelheim, BiomX, Falk, Genfit, Gilead, Intercept, Jannsen, MSD, Novartis, Phenex, and Regulus; travel grants from AbbVie, Falk, Gilead, and Intercept; and research grants from Albireo, CymaBay, Falk, Gilead, Intercept, MSD, and Takeda. Authors not named here have disclosed no conflict of interest.

Open Access This article is licensed under a Creative Commons Attribution 4.0 International License, which permits use, sharing, adaptation, distribution and reproduction in any medium or format, as long as you give appropriate credit to the original author(s) and the source, provide a link to the Creative Commons licence, and indicate if changes were made. The images or other third party material in this article are included in the article's Creative Commons licence, unless indicated otherwise in a credit line to the material. If material is not included in the article's Creative Commons licence and your intended use is not permitted by statutory regulation or exceeds the permitted use, you will need to obtain permission directly from the copyright holder. To view a copy of this licence, visit http://creativecommons.org/licenses/by/4.0/.

\section{References}

1. Dong E, Du H, Gardner L (2020) An interactive web-based dashboard to track COVID-19 in real time. Lancet Infect Dis 20(5):533534. https://doi.org/10.1016/S1473-3099(20)30120-1

2. Hanley B, Lucas SB, Youd E, Swift B, Osborn M (2020) Autopsy in suspected COVID-19 cases. J Clin Pathol 73(5):239-242. https:// doi.org/10.1136/jclinpath-2020-206522

3. Bourouiba L (2020) Turbulent gas clouds and respiratory pathogen emissions: potential implications for reducing transmission of COVID-19. JAMA - J Am Med Assoc:E1-E2. https://doi.org/10. 1001/jama.2020.4756

4. Shereen MA, Khan S, Kazmi A, Bashir N, Siddique R (2020) COVID-19 infection: origin, transmission, and characteristics of human coronaviruses. J Adv Res 24:91-98. https://doi.org/10. 1016/j.jare.2020.03.005

5. van Doremalen N, Bushmaker T, Morris DH, Holbrook MG, Gamble A, Williamson BN, Tamin A, Harcourt JL, Thornburg NJ, Gerber SI, Lloyd-Smith JO, de Wit E, Munster VJ (2020) Aerosol and surface stability of SARS-CoV-2 as compared with SARS-CoV-1. N Engl J Med 382(16):1564-1567. https://doi.org/ 10.1056/NEJMc2004973 
6. Wang D, Hu B, Hu C, Zhu F, Liu X, Zhang J, Wang B, Xiang H, Cheng Z, Xiong Y, Zhao Y, Li Y, Wang X, Peng Z (2020) Clinical characteristics of 138 hospitalized patients with 2019 novel coronavirus-infected pneumonia in Wuhan, China. JAMA 323(11):1061-1069. https://doi.org/10.1001/jama.2020.1585

7. McMichael TM, Clark S, Pogosjans S, Kay M, Lewis J, Baer A, Kawakami V, Lukoff MD, Ferro J, Brostrom-Smith C, Riedo FX, Russell D, Hiatt B, Montgomery P, Rao AK, Currie DW, Chow EJ, Tobolowsky F, Bardossy AC, Oakley LP, Jacobs JR, Schwartz NG, Stone N, Reddy SC, Jernigan JA, Honein MA, Clark TA, Duchin JS, Fagalde MS, Lenahan JL, Maier EB, Sykes KJ, Hatt G, Whitney H, Huntington-Frazier M, Gonzales E, Mummert LA, Smith HG, Stearns S, Benoliel E, McKeirnan S, Morgan JL, Smith D, Hope M, Hatley N, Barnard LM, Schwarcz L, Yarid N, Yim E, Kreider S, Barr D, Wilde N, Dorman C, Lam A, Harris J, Bruce H, Spitters C, Zacks R, Dyal J, Hughes M, Carlson C, Cooper B, Banks M, McLaughlin H, Balajee A, Olson C, Zane S, Ali H, Healy J, Schmit K, Spicer K, Chisty Z, Tanwar S, Taylor J, Nolen L, Bell J, Hatfield K, Arons M, Kimball A, James A, Methner M, Harney J (2020) COVID-19 in a long-term care facility - King county, Washington, February 27-March 9, 2020. vol 69. Dep Health Hum Serv. https://doi.org/10.15585/MMWR.MM6912E1

8. Liu Y, Yan LM, Wan L, Xiang TX, Le A, Liu JM, Peiris M, Poon LLM, Zhang W (2020) Viral dynamics in mild and severe cases of COVID-19. Lancet Infect Dis 20(6):656-657. https://doi.org/10. 1016/S1473-3099(20)30232-2

9. Xiao AT, Tong YX, Zhang S (2020) Profile of RT-PCR for SARSCoV-2: a preliminary study from 56 COVID-19 patients. Clin Infect Dis. https://doi.org/10.1093/cid/ciaa460

10. Wu Y, Guo C, Tang L, Hong Z, Zhou J, Dong X, Yin H, Xiao Q, Tang Y, Qu X, Kuang L, Fang X, Mishra N, Lu J, Shan H, Jiang G, Huang X (2020) Prolonged presence of SARS-CoV-2 viral RNA in faecal samples. Lancet Gastroenterol Hepatol 5(5):434-435. https:// doi.org/10.1016/S2468-1253(20)30083-2

11. Xiao F, Tang M, Zheng X, Liu Y, Li X, Shan H (2020) Evidence for gastrointestinal infection of SARS-CoV-2. Gastroenterology 158(6):1831-1833 e1833. https://doi.org/10.1053/j.gastro.2020. 02.055

12. Lax SF, Skok K, Zechner P, Kessler HH, Kaufmann N, Koelblinger C, Vander K, Bargfrieder U, Trauner M (2020) Pulmonary arterial thrombosis in COVID-19 with fatal outcome: results from a prospective, single-center, Clinicopathologic Case Series. Ann Intern Med. https://doi.org/10.7326/M20-2566

13. Pfefferle S, Reucher S, Norz D, Lutgehetmann M (2020) Evaluation of a quantitative RT-PCR assay for the detection of the emerging coronavirus SARS-CoV-2 using a high throughput system. Euro Surveill 25(9). https://doi.org/10.2807/1560-7917. ES.2020.25.9.2000152

14. Poljak M, Korva M, Knap Gasper N, Fujs Komlos K, Sagadin M, Ursic T, Avsic Zupanc T, Petrovec M (2020) Clinical evaluation of the cobas SARS-CoV-2 test and a diagnostic platform switch during 48 hours in the midst of the COVID-19 pandemic. J Clin Microbiol. https://doi.org/10.1128/JCM.00599-20

15. Beasley MB (2010) The pathologist's approach to acute lung injury. Arch Pathol Lab Med 134(5):719-727. https://doi.org/10.1043/ 1543-2165-134.5.719

16. Marshall RP, Bellingan G, Webb S, Puddicombe A, Goldsack N, McAnulty RJ, Laurent GJ (2000) Fibroproliferation occurs early in the acute respiratory distress syndrome and impacts on outcome. Am J Respir Crit Care Med 162(5):1783-1788. https://doi.org/10. 1164/ajrccm.162.5.2001061

17. Puelles VG, Lutgehetmann M, Lindenmeyer MT, Sperhake JP, Wong MN, Allweiss L, Chilla S, Heinemann A, Wanner N, Liu S, Braun F, Lu S, Pfefferle S, Schroder AS, Edler C, Gross O, Glatzel M, Wichmann D, Wiech T, Kluge S, Pueschel K, Aepfelbacher M, Huber TB (2020) Multiorgan and renal tropism of SARS-CoV-2. N Engl J Med. https://doi.org/10.1056/ NEJMc2011400

18. Cheung KS, Hung IF, Chan PP, Lung KC, Tso E, Liu R, Ng YY, Chu MY, Chung TW, Tam AR, Yip CC, Leung KH, Yim-Fong Fung A, Zhang RR, Lin Y, Cheng HM, Zhang AJ, To KK, Chan KH, Yuen KY, Leung WK (2020) Gastrointestinal manifestations of SARS-CoV-2 infection and virus load in fecal samples from the Hong Kong cohort and systematic review and meta-analysis. Gastroenterology S0016-5085(0020)30448-30440. https://doi.org/ 10.1053/j.gastro.2020.03.065

19. Zheng S, Fan J, Yu F, Feng B, Lou B, Zou Q, Xie G, Lin S, Wang R, Yang X, Chen W, Wang Q, Zhang D, Liu Y, Gong R, Ma Z, Lu S, Xiao Y, Gu Y, Zhang J, Yao H, Xu K, Lu X, Wei G, Zhou J, Fang Q, Cai H, Qiu Y, Sheng J, Chen Y, Liang T (2020) Viral load dynamics and disease severity in patients infected with SARSCoV-2 in Zhejiang province, China, January-March 2020: retrospective cohort study. BMJ 369:m1443. https://doi.org/10.1136/ bmj.m1443

20. Huang Y, Chen S, Yang Z, Guan W, Liu D, Lin Z, Zhang Y, Xu Z, Liu X, Li Y (2020) SARS-CoV-2 viral load in clinical samples of critically ill patients. Am J Respir Crit Care Med. https://doi.org/10. 1164/rccm.202003-0572LE

21. Peng L, Liu J, Xu W, Luo Q, Chen D, Lei Z, Huang Z, Li X, Deng $\mathrm{K}$, Lin B, Gao Z (2020) SARS-CoV-2 can be detected in urine, blood, anal swabs, and oropharyngeal swabs specimens. J Med Virol. https://doi.org/10.1002/jmv.25936

22. Wang W, Xu Y, Gao R, Lu R, Han K, Wu G, Tan W (2020) Detection of SARS-CoV-2 in different types of clinical specimens. JAMA-J Am Med Assoc 323(18):1843-1844. https://doi.org/10. 1001/jama.2020.3786

23. Zhang W, Du RH, Li B, Zheng XS, Yang XL, Hu B, Wang YY, Xiao GF, Yan B, Shi ZL, Zhou P (2020) Molecular and serological investigation of 2019-nCoV infected patients: implication of multiple shedding routes. Emerg Microbes Infect 9(1):386-389. https:// doi.org/10.1080/22221751.2020.1729071

24. Bosmuller H, Traxler S, Bitzer M, Haberle H, Raiser W, Nann D, Frauenfeld L, Vogelsberg A, Klingel K, Fend F (2020) The evolution of pulmonary pathology in fatal COVID-19 disease: an autopsy study with clinical correlation. Virchows Arch. https://doi.org/10. 1007/s00428-020-02881-x

25. Katzenstein AL, Bloor CM, Leibow AA (1976) Diffuse alveolar damage-the role of oxygen, shock, and related factors. A review. Am J Pathol 85(1):209-228

26. Xu Z, Shi L, Wang Y, Zhang J, Huang L, Zhang C, Liu S, Zhao P, Liu H, Zhu L, Tai Y, Bai C, Gao T, Song J, Xia P, Dong J, Zhao J, Wang FS (2020) Pathological findings of COVID-19 associated with acute respiratory distress syndrome. Lancet Respir Med 8(4): 420-422. https://doi.org/10.1016/S2213-2600(20)30076-X

27. Schaefer IM, Padera RF, Solomon IH, Kanjilal S, Hammer MM, Hornick JL, Sholl LM (2020) In situ detection of SARS-CoV-2 in lungs and airways of patients with COVID-19. Mod Pathol. https:// doi.org/10.1038/s41379-020-0595-Z

28. Tang JW, To KF, Lo AW, Sung JJ, Ng HK, Chan PK (2007) Quantitative temporal-spatial distribution of severe acute respiratory syndrome-associated coronavirus (SARS-CoV) in post-mortem tissues. J Med Virol 79(9):1245-1253. https://doi.org/10.1002/jmv. 20873

29. Wolfel R, Corman VM, Guggemos W, Seilmaier M, Zange S, Muller MA, Niemeyer D, Jones TC, Vollmar P, Rothe C, Hoelscher M, Bleicker T, Brunink S, Schneider J, Ehmann R, Zwirglmaier K, Drosten C, Wendtner C (2020) Virological assessment of hospitalized patients with COVID-2019. Nature 581(7809):465-469. https://doi.org/10.1038/s41586-020-2196-x

30. Basso C, Calabrese F, Sbaraglia M, Del Vecchio C, Carretta G, Saieva A, Donato D, Flor L, Crisanti A, Dei Tos AP (2020) Feasibility of postmortem examination in the era of COVID-19 
pandemic: the experience of a Northeast Italy University Hospital. Virchows Arch. https://doi.org/10.1007/s00428-020-02861-1

31. La Scola B, Le Bideau M, Andreani J, Hoang VT, Grimaldier C, Colson P, Gautret P, Raoult D (2020) Viral RNA load as determined by cell culture as a management tool for discharge of SARS-CoV-2 patients from infectious disease wards. Eur J Clin Microbiol Infect Dis 39(6):1059-1061. https://doi.org/10.1007/ s10096-020-03913-9

32. He X, Lau EHY, Wu P, Deng X, Wang J, Hao X, Lau YC, Wong JY, Guan Y, Tan X, Mo X, Chen Y, Liao B, Chen W, Hu F, Zhang
Q, Zhong M, Wu Y, Zhao L, Zhang F, Cowling BJ, Li F, Leung GM (2020) Temporal dynamics in viral shedding and transmissibility of COVID-19. Nat Med 26(5):672-675. https://doi.org/10. 1038/s41591-020-0869-5

Publisher's note Springer Nature remains neutral with regard to jurisdictional claims in published maps and institutional affiliations. 